\title{
Place Attachment and Concern in Relation to Family Forest Landowner Behavior
}

\author{
Jessica Leahy * and Patrick Lyons
}

check for

updates

Citation: Leahy, J.; Lyons, P. Place Attachment and Concern in Relation to Family Forest Landowner Behavior. Forests 2021, 12, 295. https:// doi.org/10.3390/f12030295

Academic Editor: Rebecca Jordan

Received: 23 December 2020

Accepted: 25 February 2021

Published: 3 March 2021

Publisher's Note: MDPI stays neutral with regard to jurisdictional claims in published maps and institutional affiliations.

Copyright: (c) 2021 by the authors. Licensee MDPI, Basel, Switzerland. This article is an open access article distributed under the terms and conditions of the Creative Commons Attribution (CC BY) license (https:/ / creativecommons.org/licenses/by/ $4.0 /)$.
School of Forest Resources, University of Maine, Orono, ME 04469, USA; patrick.w.lyons@gmail.com

* Correspondence: jessica.leahy@maine.edu; Tel.: +1-207-581-2834

\begin{abstract}
Contemporary approaches to studying family forests have identified distinct subgroups of landowners through segmentation analysis. Our study expands on this approach, incorporating the concept of place to provide a novel perspective on how the cognition and emotions that create place attachment and landowner concerns influence certain landowner behaviors. We specifically modeled legacy planning and future landowner ownership behavioral intentions/behaviors. A mail survey was administered to a statewide sample of Maine family forest landowners that measured place attachment and landowner concerns regarding biophysical and social conditions on their woodland. Results based on the 878 respondents (54.9\% response rate) indicated place attachment and landowner concern are related to legacy planning, land ownership, and development behavioral intentions, and when considered in conjunction with segmentation analysis, it was found the majority of family forest landowners in the sample experienced strong place attachment and moderate levels of concern. Our study suggests that forest outreach, forest policies and additional family forest research should further consider and incorporate the intangibles of the landowner experience.
\end{abstract}

Keywords: family forests; private woodland owners; place attachment; concern; landowner attitudes; landowner behaviors; legacy planning; succession planning; residential development

\section{Introduction}

The USDA Forest Service estimates 4 out of every 10 acres of forested land in the United States are held by family forest landowners [1,2]. Over the past few decades many of these landowners have subdivided or sold their land, with the number of family forest landowners in the northern United States increasing by nearly 20 percent from 1993 to 2006. In that same time period, the average size of family forest holdings decreased from 25 to 20 acres in the northern region [3]. The advanced age of landowners is in part a catalyst for this trend. Already there are indications that these new family forest landowners have changing preferences and are less likely to support traditional forest management practices [1] or open access to private land [4]. Research also indicates family forest landowners have shown family legacy to be increasing in importance among ownership objectives [1,3]. Moreover, Majumdar et al. [5] identified a significant difference in the motivations and management practices between inheritor and non-inheritor family forest landowners, finding inheritors were significantly more likely to engage in active forest management through the production of both timber and non-traditional forest products (NTFP) when compared to non-inheritors. Although, legacy planning behaviors of family forest owners are an area of growing inquiry [6-8], place attachment and landowner concern have yet to be explored as explanatory variables.

The development pressure created by the construction of primary dwellings and vacation homes increases both forest fragmentation and land clearing, and, as a result, parcelization has compromised watershed, wildlife and ecosystem sustainability and further complicated cooperation among this heterogeneous group of landowners which hold divergent management goals, backgrounds, attitudes and behaviors [9,10]. Many studies have examined development choices, including conservation easements that prevent 
development, from an economic perspective such as Song, Aguilar, and Butler [11]. Conservation easements are a key mechanism available for landowners to prevent development, and are seen as a way to preserve the landscape character [12]. Landowners can possess psychological concerns such as worrying about burdening heirs with conservation restrictions [12]. Research on landowner development and subdivision decisions suggest that there are diverse and complex factors that may influence land ownership and development choices [12-15], which may also extend to other non-economic constructs such as place attachment and landowner concern.

Segmentation analysis based on ownership motivations and management objectives has proven to be effective in numerous landowner studies, addressing management preferences [10] and land tenure and inheritance [5,16]. Segmentation analysis can also be used to support social marketing techniques by identifying landowner groups deemed to be a priority or receptive to education and then focusing limited resources to communicate with these groups more effectively. Information on demographics, management practices, and communication preferences is useful to better understand family forest landowners, but these are not the only data appropriate to employ in segmentation analysis. Increasingly, gender is a variable of interest and has emerged as important in legacy planning decisions [8] and landowner decisions [14]. Other constructs, such as place attachment and landowner concern, can offer further perspectives on family forest landowners' attitudes, values and behavior. This alternative perspective is especially important to better understand the evolving ownership objectives of this dynamic and rapidly changing landowner group [3].

Measuring the difference in ownership values and goals (e.g., timber income, wildlife habitat, recreation) is one way to consider the variability in landowners and their potential conservation behaviors. A different and important perspective is to estimate the various ways and degree to which landowners relate to their land, or are "attached" to it. Place and place attachment are concepts that represent a separate paradigm employed heavily by human dimensions researchers to explore how values and attitudes towards the environment influence human behavior [17-19]. Furthermore, we consider landowner concern about various aspects of ownership from forest health to property taxes as a potential driver of family forest landowner behavior. Adopting the conceptual place attachment framework used by Stedman [20], as well as constructing a new landowner concern scale, the objectives of this study are to:

1. Identify place meanings and evaluative beliefs held by family forest landowners and how those perceptions influence place attachment and landowner concern.

2. Explore the relationship between place attachment, landowner concern, and segments of family forest landowners.

3. Determine the relationship between landowner behaviors/behavioral intentions, place attachment and landowner concern.

\section{Literature Review}

The concept of place is understood to be more than the physical environment; it is the human experience that creates meaning, thoughts and emotions [21]. Places are "the fusions of human and natural order," imbued with meanings, objects and activities that have a significant influence on individual and group identity [22]. It is important to acknowledge that place may have different meanings for different ethnic groups [23]. Within the human dimensions of natural resources discipline, place has been used to study the meanings individuals and communities have toward their environment in a variety of resource-rich settings, such as national scenic rivers [19] and state parks [24]. Its application to private landowners has been rather limited $[17,20,25]$. The thoughts and emotions that create place may have significant influence on the decision-making process of a forest landowner. 
Our research uses the place concept of place attachment, which is understood as the emotional experiences and bonds people form with a place, conceptualized as an interchange of emotions and affect, knowledge and beliefs, and behaviors and actions in regards to a place [26]. Place attachment's impact on behavior may be of particular interest to foresters and natural resource professionals, as the emotional bonds individuals and groups form with certain places can significantly influence their sense of identity and how they perceive a resource should be used, often resulting in a willingness to engage in stewardship behavior $[18,20]$.

Vaske and Kobrin [18] used a two-dimensional framework where place attachment is a result of both place identity (emotional attachment) and place dependence (functional attachment). This approach perceives place identity as a psychologically cumulative effect where place helps create emotional meanings and purpose from a physical setting. It is a construction of self-identity that enhances self-esteem and fosters a sense of belongingness $[27,28]$. Place dependence represents a physical setting's ability to support the physical and psychological needs for desired activities, growing from repeated interaction with a physical setting, such as with water-based recreationists [28]. This two-dimensional framework has proved to be successful in accurately measuring place attachment's influence on various kinds of environmentally responsible behavior [18,27].

The approach to place attachment defined in Jorgensen and Stedman [17] and used by Stedman [20] conceptualizes place attachment as a unidimentional framework, where the components of identity, dependence, and attachment all coalesce into one attitude, which is best expressed as attachment. The model employed by Stedman [20] treats meanings and beliefs as separate phenomena from attachment and satisfaction, operating under the assumption that cognition or thoughts, such as place meanings and evaluative beliefs, directly influence the evaluations of a place, such as attachment and satisfaction. The concept of place satisfaction is similar to place dependence used by Vaske and Kobrin [18], in that both are a measure of the quality of a place and its ability to provide basic needs. Stedman [20] hypothesized and subsequently determined that strong place attachment and weak satisfaction are associated with greater inclination for the practice of stewardship behavior.

Our study adopts the Stedman [20] approach to place attachment because his model was specifically designed and tested for the purposes of measuring place attachment among landowners. However, we break from their model by measuring landowner concern, not satisfaction. We hypothesize that, similarly to higher levels of place attachment, higher levels of concern for one's land leads to increased stewardship behavior. Like place dependence [18] and satisfaction [20], concern is an evaluation of the perceived quality of a setting. Measuring concern for biophysical and social aspects of forestland is commonly used in family forest research to both assess landowner perceptions about the health of their land and its ability to provide the experiences and resources needed to achieve ownership goals and objectives [16,29]. Assuredly, satisfaction and concern are separate and distinct constructs, but both are understood as attitudes or evaluations about an object (such as a physical place) that may prompt action towards it [20]. From this, we postulated that place attachment and landowner concern influenced family forest landowners' willingness to partake in certain behaviors. Given the pressing issues related to legacy planning and residential development, we focused on behaviors that can significantly impact intergenerational transfer of land and development. Previous studies have focused on place attachment's influence on similar behavioral concepts, though only measuring one or a small number of behaviors and none specific to family forest owners $[18,20]$.

\section{Materials and Methods}

For our study, a mail survey was administered using the four-wave Tailored Design Method recommended by Dillman [30]. Property tax records for landowners in Maine came from the University of Maine's property tax record database. The database was built by requesting the publicly available tax records from all organized towns in Maine. 
Half of all organized townships in Maine supplied the requested information. The survey was administered by mail to 1000 randomly selected family forest landowners in Maine holding 10 to 1000 acres. The survey had a response rate of 54.9 percent $(n=482)$, with 122 surveys returned as undeliverable, and 46 surveys dropped from analysis due to missing values. In measuring non-response bias, Armstrong and Overton [31] have shown that later respondents have a tendency to be like non-respondents. Survey respondents were divided between first and last wave respondents and comparisons were made on age, gender, education, acres owned, absentee landowners, and management plans. These comparisons revealed no significant difference between first and last wave respondents.

Data on demographic information about respondents, their management objectives, concern regarding their land, and information-seeking behavior were collected, in addition to the survey measuring three place concepts: place meanings, evaluative beliefs, and place attachment. The model used was adapted from Stedman [20] and variables used to measure the concepts were developed using previous research $[18,20,24]$ and the USDA Forest Service National Woodland Owner Survey (NWOS) [1].

Maximum likelihood factor analysis was used to identify variability among questions measuring place meanings, evaluative beliefs, place attachment and landowner concern. A factor loading criterion of 0.50 was used to establish significant association among survey items [32]. Correlated variables were then summated into individual factors [33].

Cluster analysis was run using the twelve standard NWOS questions addressing family forest ownership objectives to identify landowner' segments. This form of analysis was used as it yields statistically significant and distinct segments of family forest landowners, accommodating the heterogeneous nature of their values and attitudes $[10,29,34]$. The k-means clustering assigned the survey participants to their respective segments based on responses to the ownership objectives, measuring level of importance on a 5-point Likert scale. In exploring the appropriate number of landowner segments, two-, three-, four-, and five-cluster solutions were analyzed, eventually arriving at a four-cluster solution based on ease and effectiveness of interpretation.

Logistic regression was used to measure the influence of place attachment, landowner concern, and sociodemographic variables on landowner behavior. Eight models were established, four for legacy planning behaviors/behavioral intentions (have a will, create a will, have an easement, join the current use tax program) and four for land ownership and development behaviors (sell land, give land to heirs, subdivide, buy more land). The independent variables were place attachment (summated rating scale), concern (summated rating scale), and the following control variables: number of acres owned, miles from woodlot, age, education level, and gender. Due to the exploratory nature of this analysis we set acceptable probability levels for rejecting the null hypothesis for the model at $p<0.10$, with the critical $p$-value for all other statistical tests $p<0.10$ as well.

\section{Results}

\subsection{Place Meanings and Evaluative Beliefs' Effect on Place Attachment and Landowner Concern}

In exploring place meanings, maximum likelihood factor analysis found a two-factor solution accounting for 50 percent of scale variation for survey questions measuring place meanings, here called Place Meanings and Community Meanings (Table 1). Regarding Place Meanings, the majority of survey participants agreed that their land was a place of high environmental quality and the real "Maine." They were less likely to agree that their land was a pristine wilderness. Similarly, for the Community Meanings scale respondents predominantly felt their land was a community of friendly people and a special place to raise their family. Maximum likelihood factor analysis also identified a two-factor solution for evaluative beliefs explaining 40 percent of the variance, here called Impacted Forestland Beliefs and Scenic Beliefs (Table 1). The majority of participants indicated they believed their land to be relatively unscathed, with low numbers identifying their land as in a crowded area or developed, contributing to the Impacted Forestland Beliefs scale. 
Alternatively, regarding Scenic Beliefs, a great majority of landowners believed their land to be peaceful, scenic, and having many species of wildlife and plants.

Table 1. Factor analysis of symbolic place meanings and evaluative beliefs scales.

\begin{tabular}{|c|c|c|c|}
\hline $\begin{array}{c}\text { Symbolic Place Meanings } \\
\text { My Land Is: }\end{array}$ & Agree (\%) & $\begin{array}{l}\text { Factor Loadings } \\
\text { Place Meanings }\end{array}$ & $\begin{array}{c}\text { Factor Loadings } \\
\text { Community } \\
\text { Meanings }\end{array}$ \\
\hline A place of high environmental quality & 76.1 & 0.768 & 0.239 \\
\hline A place to escape from civilization & 69.8 & 0.732 & 0.005 \\
\hline The real "Maine" & 73.9 & 0.732 & 0.282 \\
\hline A pristine wilderness & 52.9 & 0.709 & 0.055 \\
\hline A community of friendly people & 74.9 & 0.040 & 0.744 \\
\hline A place that contributes to the character of my community & 66.6 & 0.402 & 0.712 \\
\hline Land that represents a way of life in my community & 65.8 & 0.384 & 0.641 \\
\hline A special place for my family & 77.9 & 0.321 & 0.607 \\
\hline Eigenvalue & & 3.566 & 1.429 \\
\hline Percent of Variance & & 35.664 & 14.293 \\
\hline Alpha & & 0.750 & 0.756 \\
\hline $\begin{array}{l}\text { Evaluative Beliefs } \\
\text { My Land: }\end{array}$ & Agree (\%) & $\begin{array}{l}\text { Factor Loadings } \\
\text { Impacted } \\
\text { Forestland Beliefs }\end{array}$ & $\begin{array}{l}\text { Factor Loadings } \\
\text { Scenic Beliefs }\end{array}$ \\
\hline Is in an area that is developed & 23.5 & 0.799 & -0.079 \\
\hline Is in an area that is crowded & 7.8 & 0.778 & -0.091 \\
\hline Is close to land that is likely to be developed in the near future & 35.5 & 0.716 & 0.120 \\
\hline Is surrounded by houses and/or camps & 25.9 & 0.668 & -0.066 \\
\hline Is important to protecting water quality & 72.8 & 0.160 & 0.745 \\
\hline Is peaceful & 93.1 & -0.192 & 0.731 \\
\hline Has many species of wildlife and plants & 91.9 & -0.026 & 0.690 \\
\hline Is scenic & 80.5 & -0.054 & 0.687 \\
\hline Eigenvalue & & 2.886 & 2.303 \\
\hline Percent of Variance & & 22.201 & 17.714 \\
\hline Alpha & & 0.739 & 0.657 \\
\hline
\end{tabular}

Maximum likelihood factor analysis found a single dimension for place attachment, accounting for 69 percent of variance and a Cronbach's alpha of 0.950 (Table 2). Survey participants indicated high levels of place attachment, with the large majority feeling that in regards to their land, they can really be themselves there, it means a lot to them, and they are very attached to it. Landowner concern was assessed by measuring concern for a variety of biophysical and social issues impacting forestland, such as concern about the risk of wildland fire and concern for endangered species. Factor analysis indicated that questions could be summated into a single, reliable scale with a Cronbach's alpha of 0.895 (Table 2). Landowners were most concerned with high property taxes, misuse of their land, and keeping land intact for their heirs. 
Table 2. Factor analysis of place attachment and landowner concern scales.

\begin{tabular}{|c|c|c|c|}
\hline $\begin{array}{c}\text { Attachment } \\
\text { In Regards to Your Land }\end{array}$ & $\begin{array}{c}\text { Agree and Strongly } \\
\text { Agree (\%) }\end{array}$ & Mean $^{a}$ & Factor Loading \\
\hline I feel like I can really be myself there & 86.0 & 4.53 & 0.766 \\
\hline It means a lot to me & 88.4 & 4.52 & 0.843 \\
\hline I am very attached to it & 84.3 & 4.40 & 0.837 \\
\hline I identify strongly with it & 83.7 & 4.39 & 0.849 \\
\hline I feel it is a part of me & 79.9 & 4.33 & 0.832 \\
\hline I feel happiest when I am there & 76.8 & 4.26 & 0.833 \\
\hline It reflects the type of person I am & 78.8 & 4.26 & 0.845 \\
\hline I really miss it when I am away too long & 76.8 & 4.26 & 0.795 \\
\hline I feel a sense of pride in my heritage when I am there & 72.0 & 4.17 & 0.694 \\
\hline It is my favorite place to be & 74.6 & 4.16 & 0.840 \\
\hline For the things I enjoy most, no other place compares & 63.9 & 3.89 & 0.818 \\
\hline No other place compares to my land & 61.2 & 3.85 & 0.749 \\
\hline Eigenvalue & 8.265 & & \\
\hline Percent of Variance & 69.000 & & \\
\hline Alpha & 0.950 & & \\
\hline $\begin{array}{l}\text { Landowner Concern } \\
\text { Level of Concern }\end{array}$ & $\begin{array}{c}\text { Concerned and } \\
\text { Extremely Concerned (\%) }\end{array}$ & Mean $^{b}$ & Factor Loading \\
\hline High property taxes & 51.1 & 3.67 & 0.569 \\
\hline Misuse of land, such as vandalism or dumping & 45.0 & 3.36 & 0.723 \\
\hline Keeping land intact for my children or other heirs & 44.3 & 3.34 & 0.536 \\
\hline Insects or plant diseases & 42.2 & 3.34 & 0.708 \\
\hline Fire & 41.3 & 3.26 & 0.690 \\
\hline Trespassing or poaching & 41.2 & 3.26 & 0.659 \\
\hline Development of nearby lands & 35.8 & 3.02 & 0.603 \\
\hline Air and water pollution & 34.6 & 3.00 & 0.641 \\
\hline Wind or ice storms & 27.9 & 2.88 & 0.648 \\
\hline Damage or noise from motorized vehicles & 32.4 & 2.82 & 0.637 \\
\hline Undesirable plants & 29.4 & 2.81 & 0.659 \\
\hline People stealing trees & 27.5 & 2.71 & 0.669 \\
\hline Regulations that restrict harvests & 26.4 & 2.66 & 0.568 \\
\hline Lawsuits & 18.3 & 2.43 & 0.587 \\
\hline Wild animals, such as deer & 20.8 & 2.26 & 0.481 \\
\hline Lack of new trees & 13.5 & 2.06 & 0.581 \\
\hline Dealing with an endangered species & 11.7 & 2.04 & 0.559 \\
\hline Domestic animals, such as cattle & 9.4 & 1.69 & 0.533 \\
\hline Eigenvalue & 6.864 & & \\
\hline Percent of Variance & 36.125 & & \\
\hline Alpha & 0.895 & & \\
\hline
\end{tabular}

${ }^{\mathrm{a}}$ Mean based on 5 -point Likert scale $1=$ Strongly disagree, $5=$ Strongly agree, ${ }^{\mathrm{b}}$ Mean based on 5 -point Likert scale. $1=$ Not at all concerned, $5=$ Extremely concerned.

Based on Stedman [20], our study hypothesized that place attachment and landowner concern would be significantly influenced by place meanings and evaluative beliefs. Place meanings and evaluative beliefs were each summated into two scales based on factor analysis loading, while the place attachment and landowner concern scales were summated into single values. Ordinary least squared regression found that, for our study, place meanings and evaluative beliefs predicted both place attachment $(\mathrm{F}=101.448, p<0.001)$ and landowner concern $(\mathrm{F}=4.742, p<0.001)$ (Table 3$)$. Three of the four cognitive measures showed significant relationships for place attachment, with a strong goodness of fit for the model $\left(R^{2}=0.480\right)$. Only one of the four cognitive measures for landowner concern, Impacted Forestland Beliefs, showed a significant influence (Beta $=2.837, p=0.005$ ) and had a relatively weak goodness of fit for the model $\left(R^{2}=0.033\right)$. 
Table 3. Place meanings and evaluative beliefs effects on place attachment and landowner concern.

\begin{tabular}{|c|c|c|c|c|c|c|}
\hline & \multicolumn{3}{|c|}{ Attachment } & \multicolumn{3}{|c|}{ Concern } \\
\hline & Beta (Std.) & $t$ & Significance & Beta (Std.) & $t$ & Significance \\
\hline Constant & 5.862 & 2.090 & 0.037 * & 28.251 & 4.465 & 0.001 * \\
\hline Place Meanings & 0.276 & 6.695 & 0.001 * & 0.090 & 1.604 & 0.109 \\
\hline Community Meanings & 0.407 & 9.986 & $0.001 *$ & 0.040 & 0.717 & 0.474 \\
\hline Impacted Forestland Beliefs & -0.012 & -0.344 & 0.731 & 0.136 & 2.837 & $0.005 *$ \\
\hline \multirow[t]{3}{*}{ Scenic Beliefs } & 0.181 & 4.553 & $0.001 *$ & 0.079 & 1.450 & 0.148 \\
\hline & & & ANOVA & & & \\
\hline & SS & df & MS & $\mathrm{F}$ & Significance & Adjusted $R^{2}$ \\
\hline \multicolumn{7}{|l|}{ Attachment } \\
\hline Regression & $17,853.658$ & 4 & 4463.415 & 101.448 & 0.001 * & 0.480 \\
\hline Residual & $18,962.802$ & 431 & 43.997 & & & \\
\hline Total & $36,816.460$ & 435 & & & & \\
\hline \multicolumn{7}{|l|}{ Concern } \\
\hline Regression & 4246.804 & 4 & 1061.701 & 4.742 & 0.001 * & 0.033 \\
\hline Residual & $96,488.067$ & 431 & 223.870 & & & \\
\hline Total & $100,734.871$ & 435 & & & & \\
\hline
\end{tabular}

\subsection{Landowner Segments}

Four unique family forest landowner groups were identified using k-means cluster (Table 4). ANOVA, Pearson's chi-square and independent sample $t$-tests were used to explore how these segments differed in their ownership objectives, demographics, place attachment and landowner concern data. We adopted the landowner profile names used in Butler et al. [29] based on NWOS survey data.

Table 4. Landowner segments.

\begin{tabular}{|c|c|c|c|c|}
\hline Ownership Objectives ${ }^{1}$ & $\begin{array}{l}\text { Supplemental Income } \\
\qquad(n=191)\end{array}$ & $\begin{array}{l}\text { Working the Land } \\
\qquad(n=133)\end{array}$ & $\begin{array}{l}\text { Woodland Retreat } \\
\qquad(n=69)\end{array}$ & $\begin{array}{l}\text { Uninvolved } \\
\qquad(n=38)\end{array}$ \\
\hline Enjoy the beauty or scenery & $4.66^{\mathrm{b}}$ & $4.52^{b}$ & $4.72^{b}$ & $1.47^{\mathrm{a}}$ \\
\hline Protect nature and biodiversity & $4.22^{b}$ & $4.20^{b}$ & $4.07^{b}$ & $1.83^{\mathrm{a}}$ \\
\hline Land investment & $4.14^{\mathrm{c}}$ & $3.61 \mathrm{bc}$ & $3.44^{b}$ & $2.13^{\mathrm{a}}$ \\
\hline Part of home or vacation home & $4.57^{\mathrm{b}}$ & $4.50^{\mathrm{b}}$ & $4.64^{b}$ & $1.50^{\mathrm{a}}$ \\
\hline Part of farm or ranch & $3.53^{c}$ & $3.36^{\mathrm{b}}$ & $1.74^{\mathrm{a}}$ & $2.04^{\mathrm{a}}$ \\
\hline Privacy & $4.48^{b}$ & $4.42^{b}$ & $4.59^{b}$ & $1.55^{\mathrm{a}}$ \\
\hline Pass land on to heirs & $4.31^{\mathrm{c}}$ & $4.26^{\mathrm{c}}$ & $3.08^{b}$ & $1.97^{\mathrm{a}}$ \\
\hline Non-timber forest product & $3.53^{c}$ & $2.79^{b}$ & $1.74^{\mathrm{a}}$ & $2.04^{\mathrm{a}}$ \\
\hline Firewood & $4.31^{\mathrm{c}}$ & $2.97^{b}$ & $1.97^{\mathrm{a}}$ & $1.81^{\mathrm{a}}$ \\
\hline Timber products & $4.31^{\mathrm{c}}$ & $2.46^{\mathrm{b}}$ & $1.87^{\mathrm{a}}$ & $2.21^{\mathrm{ab}}$ \\
\hline Hunting or fishing & $4.18^{b}$ & $3.96^{b}$ & $1.54^{\mathrm{a}}$ & $1.76^{\mathrm{a}}$ \\
\hline Other recreation & $4.26^{\mathrm{c}}$ & $3.92^{\mathrm{c}}$ & $2.58^{\mathrm{b}}$ & $1.65^{\mathrm{a}}$ \\
\hline Demographics & Supplemental Income & Working the Land & Woodland Retreat & Uninvolved \\
\hline Male (\%) & $83.4^{\mathrm{a}}$ & 70.8 & 71.2 & 72.8 \\
\hline Age (years) & $59.5^{\mathrm{a}}$ & $59.3^{a}$ & $62.9^{\mathrm{a}}$ & $64.0^{\mathrm{a}}$ \\
\hline Acres owned & $132.0^{\mathrm{a}}$ & $60.1^{\mathrm{a}}$ & $86.6^{\mathrm{a}}$ & $128.0^{\mathrm{a}}$ \\
\hline Tenure (years) & $25.3^{\mathrm{a}}$ & $22.0^{\mathrm{a}}$ & $25.4^{\mathrm{a}}$ & $35.3^{\mathrm{a}}$ \\
\hline Home on Land (\%) & 68.5 & 60.3 & 69.8 & 48.6 \\
\hline Bachelor's Degree (\%) & 35.3 & 40.8 & 51.6 & 50.0 \\
\hline Place Scales & Supplemental Income & Working the Land & Woodland Retreat & Uninvolved \\
\hline Attachment $^{2}$ & $52.6^{b}$ & $51.2^{b}$ & $49.0^{\mathrm{ab}}$ & $46.5^{\mathrm{a}}$ \\
\hline Concern ${ }^{3}$ & $56.0^{\mathrm{b}}$ & $53.7^{b}$ & $47.2^{\mathrm{a}}$ & $54.1^{\mathrm{b}}$ \\
\hline
\end{tabular}

$\mathrm{a}, \mathrm{b}, \mathrm{c}=$ superscript letters denote mean separation ( $p$-value $<0.05$ ) (across landowner segments). ${ }^{1}$ Based on 5-point Likert scale. $1=$ Very unimportant, 5 = Very important. ${ }^{2}$ mean score out of possible $60 .{ }^{3}$ mean score out of possible 90. 
Supplemental Income $(n=191)$ were distinguished by both being the largest segment in the analysis and significantly placing the highest importance on all ownership objectives. This segment was unique in its high level of importance of owning land as an investment, land being a part of a farm, extraction of NTFPs, firewood, and timber. This was in addition to valuing their land to enjoy its beauty, protecting its natural diversity, and passing it on to their heirs. This landowner group had the highest levels of place attachment and landowner concern.

Working the Land $(n=133)$ landowners placed a significant emphasis on passing their land on to their children or other heirs. Additionally, this landowner group highly valued privacy, as well as protecting the biological diversity, enjoying the aesthetic aspects of their land and had the second highest rating for timber and other income-related reasons for owning land. This segment had significantly high place attachment and landowner concern, and was further distinguished by the importance they placed on hunting, fishing, and other recreation opportunities pursued on their land compared to the Uninvolved and Woodland Retreat groups.

Woodland Retreat $(n=69)$ emphasized the importance they placed on owning their land for privacy, as well as protecting nature, aesthetics and owning their land as a home. Further differentiating this segment is the lower levels of importance placed on activities that physically utilize their land, such as harvesting NTFPs, firewood, and timber, as well as not highly valuing hunting, fishing, and other forms of recreation. This group had the second lowest mean place attachment score, although not significantly different than the other segments' scores, and the significantly lowest level of landowner concern among all landowner segments.

Uninvolved $(n=38)$ represented a rather small proportion of the respondent pool and placed the lowest levels of importance on every ownership objective except for harvesting timber products. This group also had the significantly lowest level of place attachment and a high level of landowner concern among the landowner segments (Table 4). Interesting to note, despite the Uninvolved segment's difference in ownership objectives, place attachment, and landowner concern, there was no significance difference among the four segments in age, acres owned, tenure, having their primary home on their land or education, and only the Supplemental Income group were significantly more likely to be male than the other three segments (Table 4).

\subsection{Predicting Family Forest Landowner Behavior}

Using logistic regression, the relationship between place attachment, landowner concern, landowner demographic characteristics, and eight different landowner behaviors was measured. Landowner behavior questions covered topics pertaining to legacy planning and land ownership and development (Table 5). The analysis revealed that increasing landowner concern predicted the greater likelihood of giving heirs land. Our model predicted higher place attachment increased likelihood of landowners having a will and decreased their likelihood to sell their land or getting an easement. Acreage was associated with buying and selling land, giving land to heirs, and current use tax program participation. Miles lived away from nearest parcel was not significant in any of the models. Giving land to heirs, having a will, and getting an easement were more likely as participants aged, while buying more land was less likely. Education was not a significant variable in any of the models. Finally, women were more likely to be interested in buying more land than male respondents. 
Table 5. Influence of place attachment and landowner concern on behavior/behavioral intentions.

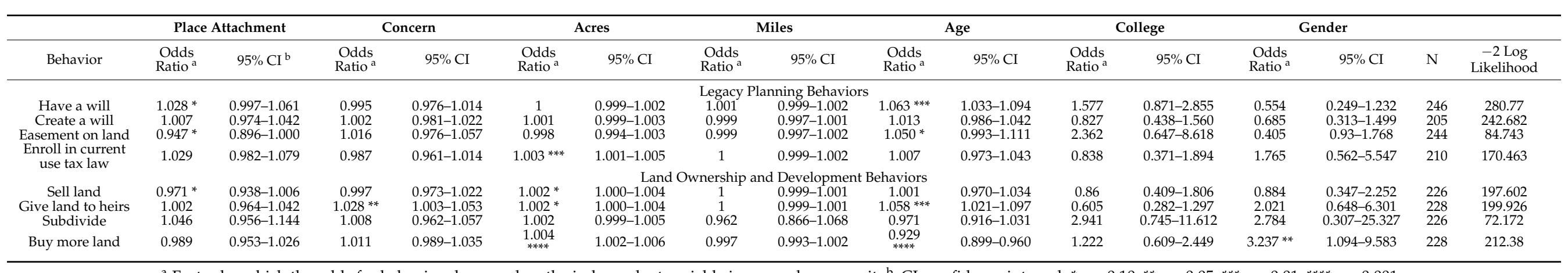

${ }^{\text {a }}$ Factor by which the odds for behavior change when the independent variable increases by one unit. ${ }^{\text {b. }}$ CI: confidence interval. ${ }^{*} p<0.10,{ }^{* *} p<0.05,{ }^{* * *} p<0.01,{ }^{* * * *} p<0.001$. 


\section{Discussion}

Our first objective was to identify place meanings and evaluative beliefs held by family forest landowners and how those perceptions influence place attachment and landowner concern. We found that two factor solutions explained the scales measuring place meanings and evaluative beliefs and single factor solutions fit the evaluations of place attachment and landowner concern. These two factor solutions for place meanings and evaluative beliefs are consistent with the outcomes of Stedman [20]. Differentiating both our and the Stedman [20] results from previous place attachment studies [18,28], place attachment was found to be a unidimensional construct with concepts of identity, dependence, and attachment all accounting for a single factor.

Our study also mirrored Stedman [20] by finding place meanings and evaluative beliefs predicted both place attachment and landowner concern. However, the goodness of fit for landowner concern was weak $\left(R^{2}=0.033\right)$, and Impacted Forestland Beliefs was the only cognitive measure to have a significant individual influence on landowner concern (Table 3). One possible explanation for this weak correlation is that our study may not have measured the full range of thoughts that landowners have toward a setting. Additionally, this weak correlation may be due to our study being the first to measure the influence of place meanings and evaluative beliefs on landowner concern, instead of landowner satisfaction as was done in Stedman [20]. Furthermore, we used a broad set of biophysical and issues to create the composite landowner concern variable. Future work should refine the measurement of landowner concern to be as closely aligned with the behavior of interest. For instance, behavior related to forest pest monitoring should be predicted using landowner concerns related specifically to forest health.

The second objective of our research was to explore the relationship between place attachment, landowner concern and segments of family forest landowners. K-means cluster analysis revealed four distinct segments of family forest landowners, demarcating groups using similar ownership objectives as previous family forest landowner segmentation studies $[10,29]$. While ANOVA revealed significant differences in ownership objectives among the segments, there was little disparity in demographics, with no significant difference in age, acres owned, tenure, having their primary home on their land, or education. However, there were significant differences in place attachment and landowner concern scores among the segments. Working the Land and Supplemental Income had significantly higher place attachment scores than the Uninvolved, while Working the Land, Uninvolved and Supplemental Income groups had significantly higher landowner concern scores than the Woodland Retreat segment. This suggests that place attachment and landowner concern are useful constructs for differentiating landowner' types.

Supplemental Income and Working the Land segments had the highest scores in both attachment and landowner concern (Table 4). These landowner' segments greatly valued the aesthetics, biological diversity and recreation opportunities their land afforded, as well as valued being able to extract natural resources such as firewood, timber and NTFPs from their land. Knowing that place attachment is the emotional bond that forms between a person and their environment, shaped through meanings, objects and activities, it would fit that these segments had a high level of attachment, as they indicated having the greatest interaction with their land. Members of the Woodland Retreat highly valued the beauty and health of their land, privacy, and it being a part of their home, but gave significantly lower importance to their land being an investment, or for any form of resource extraction, recreation activity, or family legacy. Consequently, these landowners had less to be concerned with, as they placed less importance on many functional landowner objectives and indicated lower levels of interaction with their land. The Uninvolved had a significantly higher level of landowner concern but the lowest level of place attachment. Fewer than half of these landowners lived on their land and as a group showed great indifference towards their land, with the mean rating for all ownership objectives being below the important level. In regards to their landowner concern, their higher concern appeared to 
be most likely derived from issues facing absentee landowners, such as property taxes and vandalism.

The Uninvolved segments' low place attachment and high landowner concern highlights a potential conflict in using these two concepts to predict behavior. If both scales were positively correlated, the behavior of landowners with both high place attachment and landowner concern (or in the alternative low attachment and low concern) would appear easier to predict than those with conflicting scales. These divergences would give conflicting results and be particularly difficult to interpret if individual behaviors were combined together when not measuring a single underlying theoretical construct [18] This conflict gives merit to our study's approach of measuring place attachment and landowner concern's influence on eight distinct behaviors, allowing for a more robust, detailed analysis (Table 5). For example, with lower place attachment but higher concern Uninvolved landowners may be more likely to sell their land and give land to their heirs, which are behaviors consistent with their ownership objectives. These results also suggest future studies of family forest landowners using place attachment and landowner concern would benefit from measuring other types of landowner behavior, such as more land-based and environmental aspects of forest management. However, here we can see the value of incorporating the measurement of place attachment and landowner concern in family forest research. This approach allows for a more precise understanding of behavior and behavioral intentions by incorporating proven, measurable place attachment and newer landowner concern concepts into the demographic, ownership objectives, and communication tendencies already measured in family forest landowner research.

The study's final objective was to determine the relationship among landowner behavior, place attachment, and landowner concern, hypothesizing that increased place attachment and landowner concern are associated with greater inclination for the practice of legacy planning and conservation-oriented behaviors. The three behaviors found to be significantly influenced by place attachment were the likelihood of a landowner having a will, selling land, and putting an easement on their land. Landowner concern was associated with only planning to give land to heirs. Past place attachment studies have analyzed behavior as a single summated factor [18], or using only a few behavioral measures [20], while the approach taken by our study was unique in that it used place attachment and landowner concern to predict eight distinct behaviors. Our control variables, such as age and gender, that were significant in several of the models match prior studies that identify these same variables as important in both legacy planning, and landowner ownership and development decisions $[8,14]$. The large number of behavioral measures used in our study could in part explain the failure to predict behavior for all of the logistic regression models when compared to previous studies that used a general environmentally responsible behavior scale. Despite this, the significant correlations in our study between place attachment and landowner concern with some behaviors were largely positive, agreeing with our hypothesis and aligning with previous place research [18,20]. At this point, our results partially support our hypothesis, in that as place attachment and landowner concern increase, so does the likelihood of a landowner engaging in certain behaviors.

\section{Conclusions}

Family forest landowners present the great challenge of a large group of people that hold numerous and divergent objectives, resulting in extensive and far reaching implications for the sustainability of forests. There is a pronounced need to better understand not only how family forest landowners intend to manage their land, but also to comprehend the intangible concepts of thoughts, evaluations, and motivations that influence their decisions. Our conclusions are similar to Ma and Kittredge [13] who wrote, "the results suggest the need to avoid any one-size-fits-all approach, differentiate landowners based on their engagement levels, and tailor outreach to efforts to address the interest and concerns of particular audiences" (p. 1). To move beyond traditional analysis of family forest landowners and better investigate the values and attitudes that affect behavior, theories such as 
place attachment and landowner concern should be employed to gain new perspective and insight. Place attachment theory has been used with success in a variety of natural resources disciplines, and this study hopefully furthers the dialogue on its usefulness in the study of family forest landowners and the factors that influence their decisions. Foresters are frequently trained to manage land using ownership objectives. Rather than merely measuring categorical ownership objectives, place attachment and concern reveals how landowners feel about their land.

We recommend that foresters seek to understand their landowner clients in terms of not only their particular segment (e.g., Working the Land, Woodland Retreat), but also explore their place attachment and concerns. Those with high place attachment may be more easily persuaded to take actions involving wills to ensure their intended heirs receive the land after their passing. Those with higher levels of concerns are also more likely to plan to give land to their heirs. As Kelly et al. [12] discovered some landowners are concerned that burdens will transfer to their heirs. Foresters should be encouraged to listen to landowners, perhaps using new techniques like motivational interviewing, and offer solutions to address the biophysical and social issues of concern. Outreach providers often provide content related to landowner objectives (e.g., timber-oriented workshops) but alternative programming could offer support for building strong place attachment, and focus more on landowner concerns than objectives. As family forest landowners place less importance on traditional ownership objectives, it may be time to place less emphasis on explicit management plans and objectives, and pay more credence to the intangibles of the landowner experience.

Author Contributions: Conceptualization, J.L. and P.L.; methodology, J.L. and P.L.; software, P.L.; validation, J.L and P.L., formal analysis, P.L.; investigation, P.L.; resources, J.L.; data curation, J.L.; writing—original draft preparation, P.L.; writing—review and editing, J.L.; visualization, P.L.; supervision, J.L.; project administration, J.L.; funding acquisition, J.L. All authors have read and agreed to the published version of the manuscript.

Funding: This project was supported by the USDA National Institute of Food and Agriculture McIntire-Stennis Project Number ME04-1707 through the Maine Agricultural \& Forest Experiment Station.

Institutional Review Board Statement: The study was conducted according to the guidelines of the Declaration of Helsinki, and approved by the Institutional Review Board of the University of Maine (protocol code 2010-02-15, approved 2010-02-18).

Informed Consent Statement: Informed consent was obtained from all subjects involved in the study.

Data Availability Statement: The data presented in this study are available on request from the corresponding author. The data are not publicly available due to the use of human subjects.

Acknowledgments: We acknowledge the contributions of the late David B. Kittredge who served as a mentor to J.L. and graduate committee member for P.L. and D.B.K. participated in the conceptualization and writing-review and editing, particularly encouraging us to bring social science constructs into applied research that benefits family forest landowners and other stakeholders.

Conflicts of Interest: The authors declare no conflict of interest. The funders had no role in the design of the study; in the collection, analyses, or interpretation of data; in the writing of the manuscript, or in the decision to publish the results.

\section{References}

1. Butler, B.J.; Leatherberry, E.C. America's family forest owners. J. For. 2004, 102, 4-9.

2. Butler, B.J.; Butler, S.M.; Caputo, J.; Dias, J.; Robillard, A.; Sass, E. Family Forest Ownerships of the United States, 2018: Results from the USDA Forest Service, National Woodland Owner Survey; General Technical Report. NRS-199; U.S. Department of Agriculture, Forest Service, Northern Research Station: Madison, WI, USA, 2018; 56p. [CrossRef]

3. Butler, B.J.; Ma, Z. Family forest owner trends in the Northern United States. North. J. Appl. 2011, 28, 13-18. [CrossRef]

4. Acheson, J.M. Public access to privately owned land in Maine. Maine Policy Rev. 2006, 15, 18-30. 
5. Majumdar, I.; Laband, D.; Teeter, L.; Butler, B. Motivations and land-use intentions of NIPFs: Comparing inheritors to noninheritors. Science 2009, 55, 423-432.

6. Markowski-Lindsay, M.; Catanzaro, P.; Milman, A.; Kittredge, D. Understanding family forest land future ownership and use: Exploring conservation bequest motivations. Small-Scale 2016, 15, 241-256. [CrossRef]

7. Markowski-Lindsay, M.; Catanzaro, P.; Bell, K.; Kittredge, D.; Markowitz, E.; Leahy, J.; Butler, B.; Milman, A.; Allred, S. In Forest and Intact: Designating Future Use of Family-Forest-Owned Land. J. For. 2018, 116, 357-366. [CrossRef]

8. Markowski-Lindsay, M.; Catanzaro, P.; Zimmerer, R.; Kittredge, D.; Markowitz, E.; Chapman, D. Northeastern family forest owner gender differences in land-based estate planning and the role of self-efficacy. J. For. 2020, 118, 59-69. [CrossRef]

9. Silver, E.; Leahy, J.; Weiskittel, A.; Noblet, C.; Kittredge, D.B. An evidence-based review of timber harvesting behavior among private woodland owners. J. For. 2015, 113, 490-499. [CrossRef]

10. Finley, A.O.; Kittredge, D.B. Thoreau, Muir, and Jane Doe: Different types of private forest owners need different kinds of forest management. North. J. Appl. 2006, 23, 27-34. [CrossRef]

11. Song, N.; Aguilar, F.; Butler, B. Conservation easements and management by family forest owners: A propensity score matching approach with multi-imputations of survey data. Science 2014, 60, 298-307. [CrossRef]

12. Kelly, M.; Germain, R.; Mack, S. Forest conservation programs and the landowners who prefer them: Profiling family forest owners in the New York City watershed. Land Use Policy 2016, 50, 17-28. [CrossRef]

13. Ma, Z.; Kittredge, D. How family forest owners consider timber harvesting, land sale, and conservation easement decisions: Insights from Massachusetts, USA. Int. J. For. Res. 2011. [CrossRef]

14. Markowski-Lindsay, M.; Butler, B.; Kittredge, D. The future of family forests in the USA: Near-term intentions to sell or transfer. Land Use Policy 2017, 69, 577-585. [CrossRef]

15. Bell, K.; Markowski-Lindsay, M.; Catanzaro, P.; Leahy, J. Forest-forest owner decisions, landscape context, and landscape change. Landsc. Urban. Plan. 2019, 188, 118-131. [CrossRef]

16. Kendra, A.; Hull, R.B. Motivations and behaviors of new forest owners in Virginia. For. Sci. 2005, 51, $142-154$.

17. Jorgensen, B.S.; Stedman, R.C. Sense of place as an attitude: Lakeshore owners attitudes toward their properties. J. Environ. Psychol. 2001, 21, 232-233. [CrossRef]

18. Vaske, J.J.; Kobrin, K.C. Place attachment and environmentally responsible behavior. J. Environ. Educ. 2001, 32, 16-21. [CrossRef]

19. Davenport, M.A.; Anderson, D.H. Getting from sense of place to place-based management: An interpretive investigation of place meanings and perceptions of landscape change. Soc. Nat. Resour. 2005, 18, 625-641. [CrossRef]

20. Stedman, R.C. Toward a social psychology of place: Predicting behavior from place-based cognitions, attitude, and identity. Environ. Behav. 2002, 34, 561-581. [CrossRef]

21. Tuan, Y. Space and Place: The Perspective of Experience; University of Minnesota Press: Minneapolis, MN, USA, 1977.

22. Relph, E. Place and Placelessness; SAGE Publishing Ltd.: London, UK, 1976.

23. Basso, K. Stalking with Stories: Names, Places, and Moral Narrative among the Western Apache. In Text, Play and Story: The Construction of Self and Society; Edward, B., Ed.; Waveland Press: Prospect Heights, IL, USA, 1984.

24. Davenport, M.A.; Baker, M.L.; Leahy, J.E.; Anderson, D.H. Exploring multiple place meanings at an Illinois State Park. J. Park Recreat. Admin. 2010, 28, 52-69.

25. Creighton, J.; Blatner, K.; Carroll, M. People, place and politics: The role of place attachment and conflict in forest communities. West. J. Appl. For. 2008, 23, 232-235. [CrossRef]

26. Altman, I.; Low, S.M. Place attachment: A conceptual inquiry. In Place Attachment; Altman, I., Low, S.M., Eds.; Plenum Press: New York, NY, USA, 1992.

27. Williams, D.R.; Vaske, J.J. The measurement of place attachment: Validity and generalizability of a psychometric approach. For Sci. 2003, 49, 830-840.

28. Budruk, M.; Wilhelm, S.A.; Schneider, I.E.; Anderson, D.H. Differentiating place attachment dimensions among proximate and distant visitors to two water-based recreation areas. Soc. Nat. Resour. 2011, 24, 917-932. [CrossRef]

29. Butler, B.J.; Tyrrell, M.; Feinberg, G.; VanManen, S.; Wiseman, L.; Wallinger, S. Understanding and reaching family forest owners: Lessons from social marketing research. J. For. 2007, 106, 357-362.

30. Dillman, D.A.; Smyth, J.D.; Christian, L.M. Internet, Mail, and Mixed-Mode Surveys: The Tailored Design Method; John Wiley \& Sons, Inc.: Hoboken, NJ, USA, 2009.

31. Armstrong, J.S.; Overton, T.S. Estimating nonresponse bias in mail surveys. J. Mark. Res. 1997, 14, 396-402. [CrossRef]

32. Hair, J.F.; Anderson, R.E.; Tatham, R.L.; Black, W.C. Multivariate Data Analysis, 5th ed.; Prentice Hall: Upper Saddle River, NJ, USA, 1998.

33. Vaske, J.J. Survey Research and Analysis: Applications in Parks, Recreation, and Human Dimensions; Venture Publishing: State College, PA, USA, 2008.

34. Tyson, C.B.; Broderick, C.B.; Snyder, L.B. A social marketing approach to landowner education. J. For. 1998, 96, 32-40. 